\title{
"Such Tweet Sorrow": The Explosive Impact of New Literacies on Adolescent Responses to Live Theatre
}

\author{
JOHN M. RICHARDSON \\ University of Ottawa
}

\begin{abstract}
Trips to the theatre are a regular feature of many high school language arts programs, and yet the experience of watching a play is often significantly different for a teacher than it is for a student. Placing "theatre literacy" within the context of the New London Group's definition of multiliteracies, and drawing on the work of Lankshear and Knobel as well as audience studies theorists, this article compares how a 17 year-old girl and a 43 year-old English teacher respond to a series of plays, and considers how growing up in a wireless world shapes adolescents' understanding of live theatre.
\end{abstract}

"Right minions I'm open from 2 pm for twenty. Got crystalised blueberry. Only buy from me!" - Tybalt_Cap

"In my small town the big problem is family feuding. montagues \& capulets. would love 2 talk 2 others about how to deal with *that* problem. - LaurenceFriar

"Laurencefriar I always knew you were a twit. Running low on gear when are you back? - Mercutio (Posner, 2010)

This exchange of tweets comes from the April, 2010, Royal Shakespeare Company (RSC)/Mudlark production of Such Tweet Sorrow, a Twitter version of Shakespeare's Romeo and Juliet designed to run over five weeks, with six RSC actors improvising their lines on the basis of character histories and a timeline. The "play" is one of the latest responses to the information and communication revolution that, while continuing to transform our lives in myriad ways, has landed in the midst of the live theatre tradition like a hand grenade tossed from the gods into the pit. What remains in the wreckage? What is left to salvage? Is the Information and Communication Technology (ICT) explosion all death and destruction, or in the brilliance of that initial and ongoing flash is there potential for a renewed and reinvigorated theatre to emerge?

One way to consider the many questions that arise from the brutal collision of the virtual space and the bricks-and-mortar space of live, literary theatre is to compare two mindsets, two understandings of what we can call "theatre literacy". In the back row, juggling the metaphorical ICT grenades, listening to her iPod and checking her Facebook wall even while the play starts, is a 17 year-old girl called Jasmine. Privately-educated, highly intelligent, supported by loving, culturally- and technically-savvy parents, full of opinions, jiggling her knee while sipping water from her LOVE LIFE water bottle, she is eager to get out of school, start university and embark on what is bound by the fates of the private school world to be immensely successful. Down below, reading the program while patiently waiting for the play to begin is me - a 43 year-old father of two and seasoned theatre-goer who finds himself enjoying the theatre as much for the 
chance to get out of the house for a couple of hours of thoughtful entertainment and peaceful contemplation as for profound content and theatrical pyrotechnics. No iPod, not even a cellphone, and a bicycle chained to the rack outside. Two theatre-goers, two mindsets. How do our understandings of "theatre literacy" differ? And what do those differences suggest about the ways that new technologies may be shaping adolescent responses to live, literary theatre?

\section{"Theatre Literacy" and the New London Group}

The concept of "theatre literacy" picks up on two major themes from the New London Group's seminal article, "A Pedagogy of Multiliteracies: Designing Social Futures" (1996). One is the article's pioneering definition of "multiliteracies', the expanded field that includes more than mere "letteracy" and into which theatre literacy falls. Second is the picture drawn by the Group of a world changing due, in large part, to the rise of new technologies. To consider the meaning of multiliteracies first, theatre can be seen to exist within "the multiplicity of communications channels and increasing cultural and linguistic diversity in the world" (p. 60), as one important, albeit besieged and possibly imperilled form of communication with its own unique set of symbols and signs. It combines, as the New London Group writes of other literacies, "the textual, the audio, the spatial and the behavioural" (p. 64).

The term "textual" can be taken in different directions, one of which is that a theatre-goer should understand that the performance is a version of a written play - that dialogue written on a page is translated by an actor into speech and movement on stage, and that stage directions and set descriptions imagined by an author act as a blueprint for directors and designers. Considering the performance itself as a text to be read, an audience reads the meaning of gestures, understands that a line has been taken in certain directions for certain effects, and sees that the form played out on stage is a means of communicating ideas that may be different from spectator to spectator but that all have their root in the transaction amongst page, stage, and audience.

The term "the audio" concerns what is heard - the words spoken on stage, the sound of certain effects, the impact of silence, the sound of the audience moving, rustling, laughing, crying and reacting in conjunction with, or against, the sounds created by the performers and the crew.

"The spatial" is itself a complex vocabulary, as a savvy audience member will be able to read the ways in which the theatrical space shapes and heightens responses. A series of distinct and purposeful spaces envelop the spectator from the moment she first sees the theatre and takes note of the way in which its architecture articulates meaning. Then, as she moves from concourse to lobby to inner lobby to the theatre space itself, she would be aware of the ways in which the increasingly intimate, contained spaces remove the individual from the world at large and nudge them toward the world of theatrical fantasy, a world at once of and removed from the outside. She would also be able to read the way in which the performance space functions, what Lefebvre (1991) labels the "third space" of the "classical theatrical space" that exists between the space of the actors and the space of the audience, where "actor, audience, 'characters', text, and author all come together but never become one" (p. 188). She would be aware of upstage, downstage, and off-stage, and understand the conventions that govern the relationship between actor and audience and the ways in which that relationship can change from show to show.

Finally, there is the "behavioural"- the unspoken rules of conduct that govern how an audience member acts from the moment she is dropped off at the theatre to the moment she is picked up. This is the realm of what Foucault (1977) and others have termed the "discourse" of 
theatre, the many silent but oh-so-present mechanisms that govern, control and shape a person's actions.

Within all of these components of theatrical literacy, the spectator functions. Just as someone who cannot read will helplessly turn a book in his or her hand while a reader will simply open the cover and start to decode the words, someone unaccustomed to theatre will have difficulty negotiating the experience. And just as a more experienced and educated reader may be able to draw more subtle and profound inferences from a written text, a more experienced and educated theatre-goer will be able to draw more nuanced readings from a play. Acquiring theatre literacy leads to a richer experience, and the more that people acquire theatre literacy, the greater the chance of theatres keeping their lights on in the era of social networking.

The second current of ideas from which theatre literacy can draw concerns the worldview suggested by the New London Group. Modern times, they write, spell "the definitive end of "the public' - that homogeneous imagined community of modern democratic nation states" (p. 70). It is no longer possible to assume that Canadians, or Americans, or Brits, for example, participate in shared, common, national cultures. The days when people watched the same shows on TV, listened to music from the same, limited number of traditions, or voted along party/family lines, are over. This is the era of fragmentation, personalization, and choice. Whatever position theatre naturally occupied in high culture is either gone, or going. Nothing can be assumed, least of all a common understanding or even respect for theatre.

There is, meanwhile, "an increasing invasion of private spaces by mass media culture, global community culture, and communications and information networks" (p. 70). As the power of corporate brand names increases, and as "fast capitalism" (p. 66) becomes even faster, the space available for theatre to function shrinks. When a young person's attention is captivated by the multitude of choices offered through mass media, it becomes increasingly difficult for him or her to be introduced to the cerebral pleasures, for example, of a contemporary play staged in a low budget black box theatre, or the witty repartee of an early- $20^{\text {th }}$ century play staged in Niagara-on-the-Lake or Stratford. This change is accompanied by what the New London Group calls the "conversationalization" of public discourse, in which "private lives are being made more public as everything becomes a potential subject of media discussion" (p. 70). For theatre, that shift can mean a creeping sense of irrelevance. A glance at news websites such as The New York Times or The Daily Telegraph reveals that they were last updated one or two minutes ago. Personal stories featuring celebrities, politicians or attention-seekers flash through cyberspace, images of disgraced MPs and naughty movie stars snapped on the cell-phones of self-styled citizen reporters and posted on websites within seconds. The heartbeat of culture runs quick-but the pace of live theatre remains glacial. A theatre, for example, will typically announce its upcoming fall season the preceding spring, although the plays have already long since been decided and the process of putting into place publicity campaigns, casts and teams is well underway. What may have been an acceptable lag time between a writer creating a script, or an artistic director mounting a show, is increasingly difficult to justify or explain in an age of instant communication. It is in this pluralistic society of change and challenge, in which "one cultural and linguistic standard" (p. 69) has given way to many, that theatre finds itself operating.

The challenges and opportunities posed by new technologies toward theatre can also be understood in the work of Lankshear and Knobel. Picking up on the New London Group's work, they define literacies as "socially recognized ways of generating, communicating and negotiating meaningful content through the medium of encoded texts within contexts of participation in Discourses" (Lankshear \& Knobel, 2007, p. 224). The encoded texts in this case are plays 
presented in the medium of the theatre, and the Discourse is the entire theatrical tradition within which spectators function. Lankshear and Knobel "think of new literacies having new 'technical stuff' and new 'ethos stuff"' (p. 225). The technical side concerns the ways in which new technologies allow people to engage in literacy, while the ethos side encompasses the "different kinds of values, emphases, priorities, perspectives, orientations and sensibilities" established during the print/analogue era.

This distinction between 'stuff' and 'ethos' is very helpful in understanding the impact of new technologies on theatre. Traditional theatre falls into the old, industrial world-view. A product is created by a small team of trained professionals and presented in a closed environment for a select group of paying customers. The transaction is hierarchical: by moving from the outer world to the inner, sanctified theatre space, audience members are made to feel privileged and removed. Once there, their behaviour is controlled by a variety of means, including the stern voice over the loudspeakers telling them to move to their seats, the uniformed ushers telling them where to sit and, in the case of the NAC, an artistic director who begins every show by telling the audience how to behave ("No cell phones, and if you must suck on a cough drop, please unwrap it now ..."). This mindset actually corresponds to the Web 1.0 phenomena, in which there was a strong divide between producer and consumer (Lankshear \& Knobel, 2007, p. 227), but it seems hopelessly outmoded in the context of Web 2.0, in which "production is based on 'leverage', 'collective participation', 'collaboration' and distributed expertise and intelligence” (p. 228). For an adolescent raised in the wireless world, accustomed to near constant communication with friends, and to sliding from low culture to high culture with the click of a mouse, calibrated to instant access and quick info-hits, the model of traditional theatre can appear antiquated, odd, and even antithetical to their new mindset.

In comparing the theatre literacy of a middle-aged patron like myself, and seventeen year-old Jasmine, this paper picks up on the invitation offered by Lankshear and Knobel to engage in "let's see research" (p. 230) to explore how "the striking differences in mindsets with respect to social practices involving new technologies should alert researchers to the importance of attending to how 'insiders' engage with new literacies on their (ie. Insider) terms” (p. 230).

\section{The Audience Studies Tradition}

A wealth of audience studies research has accumulated over the years, inspired in part by Roland Barthes' insistence on 'the death of the author,' a belief that broadened the study of theatre to include the audience as well as the text (Bennett, Theatre Audiences, Redux, 2006). The assertion that "a performance can activate a diversity of responses, but it is the audience which finally ascribes meaning and usefulness to any cultural product" (Bennett, 1990) lies at the heart of much of the work. Other texts examine the relationship of audience to performance, often with regard to mass media, but also in relation to theatre (Blau, 1990; Cremona, Eversmann, van Maanen, Sauter, \& Tulloch, 2004; Freshwater, 2009).

This study builds upon several scholarly research traditions, one of which considers the effects of mass media, particularly over young people. Oswell (1999), for example, provides a comprehensive survey of the reports done in post-Second World War Britain regarding the effects of television on youth, and his observations regarding the fears expressed with regard to TV foreshadow many of the fears expressed with regard to the effect of ICTs. He quotes Monica Dickens (niece of Charles) posing the following question in a 1950 issue of Woman's Own in response to the growing numbers of television sets in homes across the country: 
And what might our children become? They might become a generation who couldn't read a book, or play games out of doors, or amuse themselves with carpentry or trains or butterflies, or the hundreds of hobbies with which a child can potter so happily. (Oswell, 1999, p. 69)

Her concerns regarding the effects of television, and the rise of what an Everywoman correspondent called "TV fiends" (Oswell, 1999, p. 70) clearly foreshadow contemporary concerns regarding ICTs. One can also discern within Dickens' fear for the "hundreds of hobbies" the narrowing of options due to changes in interests or even abilities, the issue explored in this study with regard to how young people experience literary theatre. The recommendation of UK Government reports such as the Crowther Report (1959) and the Newsom Report (1963) that "teachers should teach children how to be discriminate and critical consumers of the mass media" (Oswell, 1999, p. 77) also suggests that the need for teachers to play an active role in mediating student consumption of electronic culture is an ongoing one with historical precedents. Another landmark study completed in this tradition is Morley (2003), who showed that the text is "structured in dominance by the preferred reading ... which the producers encoded and which they want the audience to receive." The audience, meanwhile "can resist, engage with and create their own meanings from the culture they receive from 'above"'. The study established that viewers are active - even combative - in their consumption of mass media, an important consideration informing the approach taken with Jasmine.

Another tradition built upon in this study is that of examining the effect of theatre on young people. Here the purposes of the studies are varied. Barker (2003), for example, compares the reception of audience members to both the film and stage versions of Crash and concludes that both film and theatre have value, and neither should be valued over the other. Gallagher and Rivière (2007) examine the fallout that results from a Toronto high school production of Da Kink in my Hair and show how drama can upset notions of authority. Harding et al. (1996) demonstrate the effectiveness of drama performances and workshops in educating youth on the dangers of drug use. In her exploration of the rise and fall of "Magpie," an Australian youth theatre, Nursey-Bray (2005) suggests that theatre targeted at young audiences specifically can have a strong dramatic impact on them, particularly when it uses unconventional forms. Lee Brown (2002) points to the complex interplay amongst the audience, the text, the audience's experiences, socio-political influences, and what is happening on stage.

Several studies look specifically at adolescent responses to live theatre, although ICTs are not often part of the picture. In one study, for example, a group of high school students is taken to an RSC production of The Cherry Orchard, Tulloch (2000) noting that students "rarely come away from the formal performance of the play separate, as it were, from their 'A-Level' reading of it. Mainly it is a matter of actors 'bringing to life' the 'flat' and 'stilted page, clarifying it" (p. 98). Here, the normalizing power of a theatre is shown to have a pretty grim effect, removing any real engagement with the play. Taking a group of Scottish school children to a production of Othello, Reason (2006) notes that the play was "equally about the social experience of being in an audience as it was about the production" (p. 240). Youngsters find the grandness of the theatre "glamorously attractive and at the same time rather alien, off-putting and stifling" (p. 229).

In a later study, Reason (2008) concludes, "theatrical competency ... depends upon the ability to translate theatrical signs into fully-fledged real world referents" (p. 12). This echoes the need for the "fuzzy thinking" referenced by Carr (2008). Researchers have also looked at how ICTs impact the relationship between audience and performer in alternative forms of theatre such as Second Life performances, street art and interactive movies (Oddey \& White, 2009). Barker 
(2003), however, points to the relative paucity of work in areas other than TV or film audience research: "... a few studies apart, there has been almost no attention to date to rather crucial questions: what do audiences seek, and get from, the experience of going to the theatre, and how do they go about the process of making sense of the productions they see?" (p. 22). Perhaps this study can contribute one small element to the ongoing exploration of that question, particularly with regard to the new and emerging impact of ICTs on the adolescent theatre experience.

\section{The Outsider}

That would be me. I have a long history with theatre, which inevitably colours my perception of it. Like lots of kids, I appeared on stage in a Scouts production, "The Gong Show," when I was about nine years old. I hated it - but somehow the experience of singing along on stage, terrified, made a lasting impression. Shy, uncertain and inarticulate, I refrained from any sort of public appearance for years. I took to the boards in high school for one play, a two-hander crime story by John Mortimer entitled The Dock Brief, and was captivated by the possibilities of theatre but annoyed and embarrassed that audience members laughed when my moustache fell off. I acted in a Caryl Churchill play, Cloud 9, during first-year university, and for the first time felt myself a reasonably accomplished member of a polished company. I learned to smoke for a Brecht play — my shortest role, but by far the most enjoyable — and got to deliver the memorable opening lines, "Booze! I need booze!" I wrote a play for my Princeton senior thesis, a wellwritten piece with little to say. I acted in plays upon graduation, toyed with the idea of trying to become an actor, and had a play enthusiastically mounted by an amateur troupe in Dundas, Ontario. I met my wife in a theatre; she was designing the poster and I was playing Dorimant in The Man of Mode. I wrote a play under the NAC playwrights' workshop - a fulfilling and stimulating experience - and experienced the joy and wonder of having a roomful of people laugh at my comedy. Most recently, I have had the pleasure of discovering through the eyes of my high school students many of my favourite plays - the dark scope of King Lear, the twisted psychological thrills of Macbeth, the disturbingly humorous banter of Pinter's The Homecoming.

All of these experiences, together with many others, have helped shape my own theatre literacy. I have had sufficient experiences in Canada, the US and the UK with very high quality theatre to be able to spot what works and what doesn't. I've also developed a fair bit of impatience with theatre that I don't feel is worthwhile. A busy, mid-career family man, I often find it impossible to justify spending time and money on a middle-of-the-road play notable more for its plodding worthiness than its electrifying appeal. Like an aging Casanova, I've had my fair share of romantic theatrical highs ... and more than my share of lows.

In looking at this question, then, I bring a wide range of theatre experiences as writer, actor, student, teacher, and theatre-goer. But I also bring a pre-Internet attitude. I learn about technology on an almost daily basis, but always think about it in terms of someone who grew up using coins for phone calls and writing letters ("You WROTE letters?" ask my sons). This means that my work with ICTs always involves a degree of self-consciousness. I am naturally resistant or uninterested in adapting much of it. Along with my friends and relatives, I am by turns dependent on, impressed by, suspicious of and, frankly, contemptuous of various types of technology. Among friends, a frequent topic of conversation concerns how the world is going mad because of technology - kids who spend their lives on Facebook, men walking down the sidewalk talking full-voice to no-one except the Bluetooth device attached to their ears, "sexting" teens, adolescents risking future careers by posting on their walls pictures of themselves doing keg-stands or smoking pot or leering at the camera, vodka and cigarette in hand. 
I also bring to this study an interest in and empathy for teenagers that is born of many years of teaching and, most recently, being a tender-hearted father to a rather wonderful, tentative, growing 14 year-old boy. And even more immediately, my work in a faculty of education has opened up the field of multiliteracies to me, as well as having caused me to begin to look more critically at my role as an English teacher. In all of these aspects, then, I am positioned as sympathetic, understanding, and interested: not a teenager, but aware of what it means to be a teenager; an avid computer user but an 'outsider' nevertheless; a theatre-lover disenchanted with much that he sees but still a believer in the potential of an ancient art to move an audience; a graduate student with some understanding of the theoretical issues, but a neophyte nevertheless. Like Nick Carroway from The Great Gatsby, a novel I teach in grade 12, I am able to function in the world of my study without being so thoroughly immersed in any one aspect of it that I lose the ability to look and listen critically.

\section{The Insider}

Jasmine, 17, was born overseas and came to Canada when she was two. She speaks in her native language at home, and converses in fluent, unaccented English at school. Her parents are both software engineers. They provide Jasmine with a cultured, tech-savvy, intellectual family environment and have been able to pay for private education since elementary school. She has travelled widely — places such as Australia, Thailand, Japan and Russia — and wants to develop her love of travel through a university degree and future career in foreign relations. At school, she is lively and opinionated, ambitious, funny and nervous, her insightful observations shot through with a crackling current of self-doubt. She talks fast, peppers her conversation with lots of "yeahs" and "likes," and accomplishes head-snapping changes of conversation between taking sips of Gatorade and spinning the bottle cap on the desktop. She has excellent marks, particularly in English, and has in grade 12 gone a long way in developing her skills of close textual analysis. She swims, works part time as a lifeguard, plays trombone in the school band, and reads occasionally. On a long car trip recently she read Jane Austen's Pride and Prejudice because she thought she might need to for English class ("You know, it's okay. Like, I don't hate it, because I know some people do and I don't"). She also read and enjoyed Malcolm Gladwell's Outliers. A natural theatre-goer? Probably. The sort of young person upon whom the future of Canada depends? Academically accomplished, culturally supported, highly literate, most likely on her way to a financially secure future: definitely.

Jasmine and I met for nearly an hour in a classroom. The basis of our conversation was a questionnaire I had developed and three plays we saw together during a series of school trips to the Canada's National Arts Centre (NAC) in Ottawa. When Jasmine's comments prompted my curiosity, I was quick to depart from the script to see how far we could take the interview. The script was recorded, transcribed, and analysed according to the methods outlined by Cresswell (2007): themes were identified within the transcript; grouped together under more general and helpful headings, and then incorporated with analysis in this report.

\section{Cultural Consumption Across the Generations}

Jasmine's experience of live performance of any sort is limited. Although her parents attend the ballet, she has only seen a couple of musicals over the years, one opera at the NAC, and a French play in grade 8 . The majority of her theatre-going experience is comprised of the plays she saw with her English class: The Blue Dragon by Quebec director wunderkind Robert Lepage; the Tony Award winning musical The Drowsy Chaperone and a stage adaptation of $A$ 
Christmas Carol. Like her peers, however, she is technologically savvy and uses a computer or portable electronic device frequently - by her estimate, "like maybe an hour and a half to two hours" per day. It is on her laptop that she does homework, watches shows, and keeps in touch with friends via Facebook, MSN, and Skype. I'm a fairly heavy laptop user myself, but here I notice the first of the many schisms between insiders and outsiders. I use my laptop to work, to keep in touch with school and a few outside friends and contacts via email, to access the Internet for a variety of research purposes (recipes, movie times, opening hours, academic articles), and to surf a handful of news sites. I don't do social networking, and I tend to watch the occasional TV show on the television. My computer life seems to have stalled at Web 1.0. For Jasmine, TV has virtually ceased to exist. "We don't even have cable anymore because no one watches," she says. She and her family catch shows via TV sites such as CTV.ca. And social networking has filled the TV void because "you have means of communicating with people who you wouldn't go and see necessarily." My media consumption remains contained within a few silos. I use the computer, I use email, I watch TV, I visit or call friends, I go to the movies - separately. For Jasmine, the boundaries have blurred and the majority of her cultural consumption takes place on her laptop.

How do these differences play out in our responses to the theatre? Jasmine has generally quite enjoyed her trips to the theatre, but is critical of many aspects of the performances. Looking ahead, she says that she might attend the theatre in the future, but that it depends upon the play. I have bought season subscriptions to the theatre over the years, just like I used to buy record albums when I was her age and still today download entire CDs. As the New London Group suggests in its comments on the lack of cultural cohesiveness, Jasmine has been raised at the cultural buffet - buying individual tracks, picking shows from a wide range of web channels, cherry-picking just what she likes from the Internet smorgasbord.

\section{New and Old Mindset Responses to the Plays}

The musical A Drowsy Chaperone was, for Jasmine, a disappointment. I found the play to be frothy, colourful, light, and overly eager to please, with few memorable songs and a cloying desire to be hilarious. Jasmine read a review online before the show that said "if you enjoy musicals, you'll really enjoy this." But for Jasmine it was "kind of funny," although some of the humour was "exaggerated." She notes, "I found it was a little bit too much for me. But it wasn't the worst thing ever, like it wasn't torturous to have to go and see it, so it was pretty good." She offers a balanced view, aided by that ever-present Internet research. Even if this production was all right, her language suggests that theatre can be "torturous," so the fact that the show didn't induce physical agony moves it into the realm of "pretty good." This suggests that Jasmine is politely eager to please; she realizes that theatre can be enormously boring, and against this fear a show that is passably entertaining stands in pleasing contrast. I have spent nearly thirty years attending theatre, good and bad, because I am committed to the artform. For Jasmine, faced with other options and the very real fear that an evening in the theatre might end up being "torturous," it is unlikely that theatre will loom large in her future unless she hears about a production - probably via the Internet - that is a guaranteed hit. Goodbye theatre subscriptions; hello rush seats and individual ticket sales.

The second play in our series, A Christmas Carol, told its familiar story through what I thought was a stunning use of darkness - deep shadows, sumptuous black costumes, the gloom of $19^{\text {th }}$ century London lit up only very sparingly by brilliant shafts of light. Jasmine's views are more categorical than they were for Chaperone: 
It was a traditional story, so it was kind of predictable ... I didn't enjoy it that much. I thought some of the singing was bad. The set was pretty cool but the entire thing was quite depressing, but I guess that is the way it was supposed to be ... The guy with the fruit, that was just weird, and there was a character, I couldn't tell whether it was male or female and it was bothering me the entire time.

Here, the differences between our perceptions of the play are revealing in terms of theatre literacy. Like Jasmine, I know the story and have seen the old black and white Alastair Sim movie countless times. But unlike her, that does not count against the experience of seeing the play. For Jasmine, a traditional story means there are no plot surprises. For me, a well-loved story is always a pleasure, and the moments of surprise lie in how the director has interpreted certain moments. For Jasmine, the singing was unacceptable but for me it was theatrical, and character-based. The ghost of Christmas future, "the guy with the fruit," I found theatrically imaginative, and the moments of gender ambiguity I enjoyed. Raised on the hyper-reality of video, Jasmine can miss the point of overt theatricality and is suspicious of props or costume elements that are not entirely lifelike. Uncertainties are the source of delicious possibilities, and I savour the echoes that run from them through the production. Jasmine likes new; I'm comfortable with old. Jasmine expects singing to be shiny and pitch-perfect as though digitally enhanced; I know that in plays it is often meant to reflect the character and I quite like the gravelly tones and the missed notes because they suggest real life. Jasmine likes things to make sense, to fit within a binary world of clear-cut, unambiguous choices. I intuitively like the old analogue world, the grooves between the tracks, the pop and whistle of scratches and dust.

\section{Responses to the Theatrical Space}

The actual experience of attending the theatre does not seem to phase Jasmine, perhaps due to the cultural capital she brings to the experience. She uses the words "interesting" and "exciting" to describe the experience of entering the building, comments on the pleasures of watching "the different kinds of people who would go to see all the plays, like the people who are really dressed up versus the random people off the street." In this we are alike, although for Jasmine there is a newness to the experience, a feeling that for an ambitious adolescent a trip to the theatre is a way to step tentatively into the adult world. She is also aware of its alienating qualities: "It just seems like a formal event ... it has that stigma of being more like a cultural thing." She feels able to go to the theatre and enjoy a show, but its formality puts it outside of the zones adolescents most naturally occupy - the family room, the school, the mall, the multiplex, the restaurant or coffee shop. While I am aware of participating in a long and storied cultural tradition, Jasmine associates high culture with "stigma," and while I may continue to feel a tingle in my spine every time I set foot in a theatre, Jasmine feels none of the respect or even awe that I feel, a middle-class man from a small town, for whom theatre still seems, even now, exalted, special, even mysterious. Instead, Jasmine speaks of the "disconnect" she feels in the theatre, commenting dispassionately that as the world turns increasingly electronic, "I don't think it will be phased out completely, but I definitely think that the popularity is ... sinking."

It would be easy to write that Jasmine dismisses the live experience out of hand, preferring life on-line to life in the flesh. But the truth is more complex, as she describes:

With web-based activities I think that you are kind of disconnected from it ... (theatre is) just like really an entire experience. And common courtesy means you're not going to walk out of the theatre, right? So you are in it for the entire 
time, whether you like or you don't like it, and you have the actual people on stage doing this for you, so you are really a lot more connected to it.

While she enjoys the self-directed nature of the web, she recognizes the lack of physical connection with others, values the liveliness of performance and the empathy she can feel for a person over a screen - even if the rules of theatre deportment mean that you can be trapped in your seat regardless of the show's quality. A recognition of the pleasures of live performance is again allied to a fear of being stuck.

Jasmine is aware of the articles in the media ascribing shorter attention spans to time spent on the web and feels that she has been affected in this way also. She views theatre warily: "You have to have an attention span," she notes, "especially if it's a long performance." Later she adds, "I feel like it takes concentration for me to actually have to sit there, and it takes effort for me to keep paying attention whereas I am used to kind of not having to put in that effort." She is more naturally attuned to the web, where she has "like, five windows open; I just go without waiting or anything." She describes a typical session:

I have an internet window, whereas say I'm doing homework or actually doing research or something and I have the Word document, and then I have music, and then I probably have a chat window open, and then I'd have my email open, then if a page is loading, I'd go to something else and I, you know, keep it. I'd always be doing something, therefore I don't need to stay focussed on one thing for a long time. I don't need to wait. So there's no patience involved whatsoever, which I guess again would be a con going to the theater, because you actually have to focus on one thing and be patient.

No-one likes a boring play, but in the industrial world mindset one expects a certain degree of boredom. When I work on my laptop I certainly procrastinate by flipping over to a news site every so often, but I would be unable to work with what I would perceive as the constant interruption of music and messages. The theatre, with its focus on the stage, feels natural to me. It reflects how I think, how I work, but Jasmine is used to a more varied stream of stimuli. She likes it. She seems scared of the possibility of insufficient stimulation. She describes herself as "pretty respectful" and "attentive until something loses my attention, and then it's really hard to get it back. If it's boring I just zone out and then I can't get back into it." For me, moments of boredom can be a pleasant reprieve from a busy family life, or can provide the opportunity for me to think about a particular aspect of the stage production without fear of losing track of the story. For Jasmine, holding onto a focus is seen as more of a struggle:

I'm looking at, I find my attention really like scattered like if something is happening or if someone else is moving or, when you are acting they say not to take attention away the main performer and I don't, but I find myself always looking for like little things that someone is doing, and if I find myself distracted by, like, the set and everything, so I actually prepare myself ... I guess it's the attention span thing again. I'm not necessarily looking at the main thing that they want me to be looking at.

My theatre viewing is relatively simple. Aware of the mechanics behind the performance, I am happy to be manipulated by it. I look where the director wants me to look. I seek out the major themes, recognize the big moments, gamely go along with the theatrical conceits. Jasmine is used to five screens of information instead of one large stage, and her eyes and her mind roam. But she does not see this as an impossible barrier. "I don't find it a deal-breaker for going to the theatre," she says. "I guess it's the type of activity that is required." She is theatre literate to the 
extent that she knows what to expect, but her position as a digital insider puts her outside of the activity. To me it seems normal; to her it seems different. "I think that as society progresses in this," she adds ominously, "it might become more problematic."

\section{The Future of Theatre in a Wireless World}

And what of the future? For Jasmine, education will play a major role in keeping theatre relevant because "the current media and everything is kind of working against it ... the way people are growing up now they are looking for a more intense ... experience." If people see plays at school and they like them, she says, "they might do it again." Here we agree entirely. I believe in the importance of theatre as a rich cultural tradition, one that can, must and will continue to comment insightfully and sensitively on many of the nuances of the human condition. Schools have a role, through their English and drama departments, to expose students to the culture that exists beyond the screen. For Jasmine, theatre can seem like a strange little activity, a world unto itself, threatened, quaint, peculiar.

And what of theatre itself? To me, the digital outsider, it is difficult to imagine theatre as much different from what I am used to. My instinct is to keep searching for the genuine, the human, the intelligent and moving. For Jasmine, to be successful, theatre must present something "new." Here she refers to the first play we saw together, Lepages's The Blue Dragon. This was a technologically impressive play, with numerous computer-generated and quite spectacular special effects. One of its most notable aspects was its use of the stage space as a screen. Using different levels, as well as a semi-translucent screen and a projector, the stage could be viewed as a computer screen, with action on several planes, plus writing and graphics. To me, the production seemed overwrought: too many special effects overwhelming a small, inconsequential story. In Lankshear and Knobel's terms, I admired all the "technical stuff," but missed the humanity in the middle of it. Jasmine had issues with the acting, and the script, but liked the technology, and sees the future of theatre in it. "I think people are looking for something more modern," she says. I ask her what she means by "modern." "Making it more interesting with technology," she says, "versus, like, people acting on stage."

For this young person, then, the future of theatre in the wireless world seems strangely people-less. This particular route could lead future audiences in a variety of directions, one of which has played out with the Royal Shakespeare Company's twitter production of Romeo and Juliet.

"A man can go seventy years without a piece of ass, but he can die in a week without a bowel movement." - Tybalt. (Reporter, 2010)

Is Twitter theatre the way forward? Is it the means to an end, meaning paid audience members in the seats of established theatres like the RSC or our own NAC, or is it the future envisioned by Jasmine, in which new technologies go beyond even the eye-catching work of Robert Lepage to transform the very essence of the experience? The impact of the new technologies revolution on live theatre-including the rise of multiliteracies, and the imperilled state of theatre literacy as defined by the New London Group and Lankshear and Knobel—is immense, profound, and ongoing. Only one thing is clear in the midst of the wreckage caused by its explosion: although I am the present of theatre, I am not the future.

The future, whatever shape it takes, belongs to Jasmine. There she is, up in the gods, chatting with a friend who is texting another friend two rows down, sharing a pair of ear buds, 
downloading the latest episode of Grey's Anatomy on her iPhone, waiting, impatiently, for the show to begin.

\section{References}

Barker, M. (2003). 'Crash', Theatre Audiences, and the Idea of Liveness. Studies in Theatre and Performance, 23 (1), 21-39.

Bennett, S. (2006). Theatre Audiences, Redux. Theatre Survey, 47 (2), 225-230.

Bennett, S. (1990). Theatre Audiences: A Theory of Production and Reception. London: Routeledge.

Carr, N. (2008, July/August). Is Google Making Us Stupid? Retrieved June 7, 2010, from The Atlantic: http://www.theatlantic.com/magazine/print/2008/07/is-google-making-usstupid/6868/

Creswell, J. W. (2007). Qualitative Inquiry \& Research Design. Thousand Oaks: Sage.

Foucault, M. (1977). Discipline and Punish. New York: Random House.

Gallagher, K., \& Riviere, D. (2007). When Drama Praxis Rocks the Boat: Struggles of Subjectivity, Audience and Performance. Research in Drama Education, 12 (3), 319-330.

Harding, C. G., Safer, L. A., Kavanagh, J., Bania, R., Carty, H., Lisnov, L., et al. (1996). Using Live Theatre Combined With Role Playing and Discussion to Examine What At-Risk Adolescents Think About Substance Abuse, Its Consequences and Prevention. Adolescence , 31 (124), 783+.

Lankshear, C., \& Knobel, M. (2007). Researching New Literacies: Web 2.0 Practices and Insider Perspectives. E-Learning , 224-116.

Lee-Brown, E. (2002). Performativity, Context and Agency: The Process of Audience Response and Its Implications for Performance. Text and Performance Quarterly, 22 (2), 138-148.

Lefebvre, H. (1991). The Production of Space. Oxford: Blackwell.

Morley, D. (2003). The Nationwide Audience. In W. Brooker, \& D. Jermyn (Eds.), The Audience Studies Reader (pp. 95-111). London: Routeledge.

New London Group. (1996). A Pedagogy of Multiliteracies: Designing Social Futures. Harvard Educational Review , 66 (1), pp. 60-92.

Nursey-Bray, R. (2005, October). Pecking at your head: the flight and fall of 'Magpie'. Australasian Drama Studies , 36-54.

Oddey, A., \& White, C. (2009). Modes of Spectating: Introduction. In Modes of Spectating (pp. 1-14). Chicago: Intellect.

Oswell, D. (1999). And What Might Our Children Become? Future Visions, Governance and the Child Television Audience in Postwar Britain. Screen, Spring, 66-87.

Posner, M. (20101, April 13). For never was a story of more woe than this of @julietcap16 and her Romeo. The Globe and Mail, p. A3.

Reason, M. (2008). Drawing The Theatrical Experience: How Children Watch Theatre. Edinburgh: imaginate.

Reason, M. (2006). Young Audiences and Live Theatre Part 2: Methods, Participation and Memory in Audience Research. Studies in Theatre and Performance , 26:3, 221-241.

Reporter, D. M. (2010, April 12). Such tweet sorrow: Romeo and Juliet get a Twitter makeover. Retrieved April 12, 2010, from dailymail.co.uk:

http://www.dailymail.co.uk/sciencetech/article-1265331/Romeo-Juliet-Twittermakeover.html 
Tulloch, J. (2000). Approaching Theatre Audiences: Active School Students and Commoditised High Culture. Contemporary Theatre Review , 10 (2), 85-104.

\section{AUTHOR BIOGRAPHY}

John M. Richardson has a B.A. (Princeton) and an M.A. (Toronto) in English and drama, a B.Ed. (Dalhousie) and an M.A. (Ed.) (Ottawa). He has worked as a writer for the federal government and EQAO, and teaches English at Ashbury College, Ottawa. Correspondence concerning this article should be addressed to the author, 199 Powell Avenue, Ottawa, Ontario, Canada, K1S 2A4. Email: john.mathew.richardson@ gmail.com. Follow John Richardson at http://twitter.com/teachlangandlit 